\title{
Structural Reforms and Fiscal Discipline in Europe
}

\author{
Alessandro Girardi · Paolo Paesani
}

Received: 24 February 2008/Accepted: 19 March 2008/Published online: 16 July 2008

(C) Springer-Verlag 2008

\begin{abstract}
In this paper we provide an overview on recent contributions on the effectiveness of the institutional framework operating in Europe to fulfil the objectives declared in the Lisbon Agenda under the fiscal constraints established in the Stability and Growth Pact. After a review of the Stability and Growth Pact as well as the Lisbon Strategy and the Sapir Report, we discuss the relations between fiscal policy and structural reform. Finally, we focus on 2D points in the EU debate on institutional reforms: government short-sightedness and the coordination of national fiscal policies at the European level.
\end{abstract}

Keywords European institutional frameworks - Stability and Growth Pact . Lisbon Strategy $\cdot$ Sapir Report

JEL Classification $\mathrm{F} 15 \cdot \mathrm{F} 55 \cdot \mathrm{H} 60 \cdot \mathrm{H} 87$

\section{Introduction}

The debate on the institutional design of the European Monetary Union was characterised by a broad consensus among politicians and academics that "stringent rules" for national fiscal policies are a prerequisite for an efficient common monetary policy. This view shaped the Maastricht Treaty and it led to the Stability and Growth Pact (SGP). Economists and policy makers also agreed with the need for structural reforms in raising growth potential and lower structural unemployment in Europe.

\footnotetext{
A. Girardi $(\bowtie) \cdot$ P. Paesani

Institute for Studies and Economic Analyses (ISAE),

University of Rome Tor Vergata, Rome, Italy

e-mail: a.girardi@isae.it

P. Paesani

e-mail: Paolo.Paesani@uniroma2.it
} 
The political consensus towards the need of more "growth and jobs" in Europe was at centre of the Lisbon Agenda.

In this paper, we provide an overview on the effectiveness of the institutional framework operating in Europe to fulfil the objectives declared in the Lisbon Agenda taking into account the constraints arising from the SGP. The structure of the paper is as follow. "The Stability and Growth Pact" illustrates the main ideas behind the SGP and the most influential contributions offered by scholars in order to improve its effectiveness even in periods of economic downturn. "The Lisbon Strategy" reviews the priorities established in the Lisbon Strategy. "The Sapir Report" discusses on the Sapir Report. "On the Fiscal Discipline and Structural Reforms Nexus" analyses the relationship between fiscal discipline and structural reforms given the current institutional architecture in Europe. In the last section examines the issue of coordination as a major source of weakness of both the SGP and the Lisbon Strategy. Bibliographical notes conclude.

\section{The Stability and Growth Pact}

The SGP has set down for ensuring sustainable public finances and to prevent highdebt countries from continuing to run high deficits and debts that could adversely affect all members in the monetary union. If the costs of unsustainable policies fall entirely within the country that carries them out, they need not be the concern of area-wide rules. However, they can have adverse spillovers in a monetary union and become a concern for other countries (Bini-Smaghi and Casini 2000). As pointed out in HM Treaury (2004), a country within a monetary union that became unable to finance its expenditure would face three options. It could: (i) default on its debts; (ii) receive direct transfers from other members of the monetary union or another international organisation to finance its expenditure; (iii) put pressure on the central bank to relax monetary policy. All three options would be harmful, for both the country involved and for other member countries. In the euro area, the Treaty explicitly rules out 'bail outs' of one member state by another or by the European Central Bank (ECB). However, to secure credibility in a monetary union, additional safeguards are needed to bolster sustainability and minimise the risk of adverse spillovers occurring. It is sometimes argued that financial markets will discipline fiscally profligate countries by increasing their borrowing costs. However, markets may not provide sufficient incentives for restraint. Market perceptions of the euro area and euro area long-term interest rates could therefore be affected adversely by the actions of one member country. In economic and monetary union (EMU), policy co-ordination and economic governance more generally is founded on the principle of an intergovernmental approach; that is member states act together to make decisions.

In principle, policy co-ordination can bring substantial gains, helping to produce a better policy mix and supporting overall economic stabilisation. However in the euro area framework, characterised by a single monetary authority with a number of decentralised fiscal authorities, policy co-ordination is intrinsically more complex because of the need for co-ordination and information sharing among the various 
fiscal authorities ('fiscal-fiscal' co-ordination) as well as effective co-ordination between the fiscal and monetary authorities ('fiscal-monetary' co-ordination). Within EMU, the loss of an independent monetary policy strengthens the case for preserving fiscal flexibility to respond to country-specific shocks, or common shocks which impact asymmetrically. An area where the SGP might have an important role to play is in allowing individual member states with low debt sufficient room to use either the automatic stabilisers fully or, where necessary, discretionary fiscal policy in responding to shocks, while ensuring the credibility of long-term fiscal objectives. Yet a criticism that has been identified in the SGP is that some countries could find themselves unable to allow the automatic stabilisers to operate fully within the constraint of the $3 \%$ deficit reference value (Eichengreen and Wyplosz 1998). Greater transparency over the long-term objectives of fiscal policy, and the national fiscal operating rules and policies that would implement them, could bolster credibility by building confidence that short-term responses to economic shocks did not jeopardise longer-term commitments.

In the light of the not-fully-convincing way of functioning of the SGP, several ideas have been put for its reform. HM Treaury (2004) provides an exhaustive list of contribution proposed by academics on that issue. Pisani-Ferry (2002) argues that Eurogroup should agree on a set of broad non-binding policy principles outlining the operation of fiscal policy to assist fiscal-fiscal co-ordination. In order to increase information exchange between the ECB and national fiscal authorities, Bini-Smaghi and Casini (2000) argue that the ECOFIN Presidency should attend meetings of the ECB Governing Council and report back to other members of the euro area more regularly. Wyplosz (2002) proposes the creation of new fiscal policy committees in each member state. These would have authority over the deficit in each country, but no say on the size and composition of expenditure or taxes. They would be given the long-term mandate of maintaining debt at a certain target, but would be able to vary the deficit in the short term to stabilise the economy. Several authors argue that independent bodies would be more credible in assessing whether discretionary fiscal policy compromised sustainability. For example, Begg et al. (2002) argue that the EU should delegate monitoring to an independent body. Fatás et al. (2003) and von Hagen (2003) argue for the creation of an independent European fiscal sustainability council to monitor the sustainability of member states' finances. Blanchard and Giavazzi (2003) argue instead that investment spending should be excluded from deficit calculations under the SGP, since this would increase transparency, permit quality public investment, and prevent pro-cyclical tightening of fiscal policy in the short run. Buiter and Grafe (2004) favour a 'permanent balance' rule, whereby the net present value of total future government future revenues (adjusted for future growth and inflation) should be at least equal to the net present value of total future expenditure, including debt repayments. Although both sides of this equation would be hard to calculate accurately, the authors see the benefits of allowing for countercyclical policy and public investment outweighing any implementation costs. Allsopp (2002) argues that a key requirement for effective co-ordination is an "appropriate and transparent monetary policy reaction function", giving national fiscal authorities a better understanding of how monetary policy would respond to economic fluctuations. Casella (2001) proposes the introduction of tradable permits 
to run deficits. Countries that wanted to run higher deficits would have to buy such permits from others before they could do so. Finally, Buti et al. (2003a, b) propose a collection of measures designed to deliver a more pragmatic interpretation of the Pact including: adjusting interpretation of the 'close-to-balance or in surplus' rule on a country-by-country basis; improving transparency; monitoring cash flows and reporting contingent liabilities; devising a sanction for member states not undertaking sufficient consolidation during economic upturns; and making implementation of the rules less partisan.

The global slowdown has tested the effectiveness of the European institutional frameworks in supporting both stability and growth. This became most apparent in November 2003, when the ECOFIN Council decided to put on hold the excessive deficit procedures for France and Germany. This prompted a dispute between the Council and the Commission that ultimately had to be resolved by the European Court of Justice and led to a reform of the SGP in both "preventive" and "corrective" dimensions of the multinational set of rules. The preventive arm of the Pact concerns the setting and attainment of appropriate medium-term budgetary objectives in order to achieve fiscal outcomes that guarantee sustainability, while also creating room for automatic fiscal stabilisation. By contrast the corrective arm is about dealing with fiscal policies that have gone astray and are in need of correction. A clear 3\% ceiling and strict excessive deficit procedure were designed to guarantee a minimum of fiscal discipline in the euro area and to anchor expectations accordingly. As to what has changed, there are several aspects of the reform, which worth mentioning:

- Introduction of differentiated "medium-term objectives" (MTOs). Each member state will present its own MTO, which should take into account the economic characteristics of each country, while maintaining a safety margin with respect to the $3 \%$ deficit limit;

- Introduction of new provisions concerning the adjustment effort that should be made in order to reach the MTO. This adjustment should be equal to $0.5 \%$ of GDP per year, as a benchmark, with more effort in good times, and possibly less in bad times;

- Both the MTOs and the adjustment path towards them will be measured in cyclically adjusted terms, in order to focus the Pact on the structural budgetary position;

- The budgetary implications of major structural reforms are to be taken into account;

- Change of the "exceptional circumstances" clause, according to which any negative growth rate, or even a period of positive but very low growth compared with the trend, can be considered exceptional;

- Introduction of a list of "other relevant factors" that have to be taken into account when assessing deficit developments in the context of the excessive deficit procedure;

- Even though the default deadline remains the "year after its identification, unless there are special circumstances", the list of other relevant factors will now serve as the basis for deciding whether special circumstances exist. 
In the view of the ECB, the new Pact ushers in a more sophisticated approach to fiscal surveillance. Under the preventive arm, the differentiation of MTOs, the adjustment path towards the MTOs and the taking into account of structural reform are all changes designed to make the Pact "make economic sense", by increasing the Pact's focus on sustainability. This has, no doubt, come in response to certain criticisms of the original framework. But this will only be the case if they are well implemented, which also means that compliance and enforcement have to improve. In many respects, the changes to the corrective arm mirror those to the preventive arm. They aim to enhance the economic rationale of the Pact by making decisions in the context of the excessive deficit procedure more conditional on a range of economic factors and circumstances. There is now more explicit flexibility and room for economic judgement. This marks a significant departure from the original emphasis on simple rules and strict compliance.

\section{The Lisbon Strategy}

Taking into account the slowing dynamics of growth and productivity of the European economy relative to other fast growing parts of the world and its aging population, the aim of the Lisbon strategy (LS) at its starting point was to look for new sources of growth that could secure more competitiveness, economic development and social security in the future. Such new sources were primarily seen in the fast development of the knowledge economy that was expected to produce higher value added of outputs and, at the same time, raise the productivity of the main production factors. The LS was launched at the European summit in March 2000. Its overall objective was to transform the EU into "the most competitive and dynamic knowledge-based economy in the world, capable of sustainable economic growth with more and better jobs and greater social cohesion" by 2010 (European Commission 2000). Through it, the European leaders envisioned the EU as a future economic "superpower", which would concurrently keep or even raise the level of its inherited social commitments (Blaszczyk 2005). Taking a closer look at the more concrete tasks defined within this process, Blaszczyk (2005) group them in five main policy areas: employment growth; knowledge economy and knowledge society development; social cohesion; environment and structural economic reforms.

The Lisbon Strategy has been equipped with two kinds of instruments to pursue its objectives. The first one is the traditional community method (the European Commission proposes drafts of regulations, the Council of Ministers and the European Parliament adopt them, the member states are responsible for the implementation). This method is to be used in areas where the EU has legal competence, notably in most important and strategic issues, such as the implementation of the single internal market, the European Patent, competition and state aid rules or the integration of financial markets in Europe. The second instrument was created to be adopted in areas of need for common action where the Community has limited or no legal competence (for instance, labour market or business climate issues as well as most measures linked to the implementation of the "knowledge 
economy"). This method, called the open method of coordination (OMC), is a framework for cooperation and coordination using the following tools: setting guidelines for the EU, combined with timetables for achieving goals; establishing quantitative and qualitative indicators and benchmarks for measuring the progress; translating European guidelines into national and regional policies; conducting periodic monitoring, evaluation and peer reviews in order to promote mutual learning. Since the OMC method is based on a voluntary participation of the member states and is not armed with any legal sanction, it can use only informal means of enforcement (so-called "blaming and shaming"). It is highly flexible and therefore can be easily adjusted to the nature of the discussed area.

Blaszczyk (2005) emphasises that the progress in the implementation of the LS significantly differed among countries. There were groups of definitely better performing countries set against decisively worse performing ones. The progress and level achieved by individual countries are compared every year by the Commission using the structural indicators and are assessed by the European Council at its spring meetings. According to the reports, the best performers in general were the Nordic countries: Sweden, Denmark and Finland. They score well in almost every aspect of the Lisbon agenda. The second best group includes the UK, the Netherlands, Ireland and Austria. These countries achieved good scores in some, but not all areas. Greece, Spain and Portugal have a relatively poor position for most indicators but they at least tried to carry out some reforms. Remaining countries are positioning themselves somewhere "in between", having progressed in some areas and stalled in others. Only Italy, remains indifferent toward Lisbon goals and even appears to be sliding backwards (Centre for European Reforms 2004, 2005).

In 2004, the European Council and the Commission decided to prepare a midterm review of the Lisbon process, to be presented to the Spring Summit in March 2005. Former Dutch Prime Minister Wim Kok was mandated by the March 2004 European Council to lead a group of experts with the objective of reviewing the Lisbon strategy. The Kok report concluded in November 2004 that little progress had been made over the first five years and recommended to refocus the agenda on growth and employment. It also underlined the need for real ownership by the member states of the reforms needed. The Commission's mid-term review had three main objectives: (i) focus on economic growth and employment by launching the idea of a "Partnership for Growth and Jobs", which would be supported by an action plan at Union level and national action plans in the member states; (ii) national member states, social partners and even citizens need to take "ownership" of the necessary reform processes; (iii) simplification, clarification and simpler reporting: there will be a single Lisbon report at EU level and one at national level.

In July 2005, the Commission presented a 'Community Lisbon programme', which will form the complement to the national action plans for growth and jobs that the member states have to finalise before October 2005. The programme consists of 50 initiatives (regulatory actions, financing actions and policy development) which have been or will be taken at EU level to refocus the EU's economic reforms agenda on growth and jobs. There are no genuinely new initiatives in the list of those measures but the Commission has grouped them together under eight "key measures 
with a high European value-added". In its January 2006 first annual progress report on the Lisbon strategy, the Commission has defined four priority areas where more action is needed. Next to repeated calls for more investment in education and research and higher employment rates, the Commission has taken on board the need to define a common EU energy policy.

\section{The Sapir Report}

In 2003, an independent study group, chaired by Prof. A. Sapir, issued a report later published by the Oxford University Press (Sapir 2003) evaluating the adequacy of and possible improvements to the EU policy framework in view of the challenges posed by the Lisbon targets and enlargement.

The report opens by pointing out that, despite fundamental institutional achievements (single market, monetary union, enlargements), the EU economic performance has been mixed. Macroeconomic stability (low inflation, low budget deficits) and cohesion (both across regions and individual) have been achieved but growth has been poor, both at the per capita and overall level, especially vis à vis the US. EU-US gap in GDP per capita can be explained by lower labour utilisation (lower hours per worker and participation, higher unemployment) and lower labour productivity (even if 'apparent' productivity is at par or higher in several EU countries). The gap in 'structural' productivity is even greater if under-utilisation of labour is factored in. Low growth is viewed as a symptom of the failure of the EU economic system, traditionally based on the assimilation of existing technologies, mass production and large firms with stable markets and labour relations, to adapt to changing circumstances (economic globalisation, strong external competition). Increasing growth requires massive reforms of economic policies and of European economic governance, this being a pre-condition for the sustainability of the European social model, and the success of enlargement. The combination of low growth and increased public spending (amongst all in view of the over-ageing of society) does not generate sustainability. In addition to that, income disparities in the EU are more important (because of the enlargement) than they used to be when the Southern Member States joined. According to the rapporteurs, expanding growth potential requires first reforms of microeconomic policies. However, there is also a need to revise some features of the current macroeconomic policy setting and to redesign cohesion policies at both the EU and national levels. Appropriate market regulation also plays a crucial role. Improving the functioning of product and factor markets requires action at both the EU and national levels. Quite often in the EU economic system, policy instruments are assigned two objectives at the same time: for example, fostering growth and improving cohesion. It would be better to assign one objective to each policy instrument. New policy designs should improve the functioning of the enlarged Union and be geared towards increasing growth both in general and in the new Member States.

The agenda, set out in the third part of the Sapir report, contains six points which focus on where EU policies and their economic management can make the greatest contribution to achieving the declared aims of sustainable growth with more and 
better jobs, continuing price stability and greater economic and social cohesion. The six-point agenda calls on the EU and its members: 1. to make the Single Market more dynamic; 2. to boost investment in knowledge; 3 . to improve the macroeconomic policy framework for EMU; 4. to redesign policies for convergence and restructuring; 5 . to achieve more effectiveness in decision-taking and regulation; 6 . to refocus the EU budget.

1. Make the Single Market more dynamic requires completing the Single Market, including financial services and the service market. Here the main recommendations are for better coordination between regulatory and competition policies to encourage market access for new entrants and to introduce a more pro-active policy to support labour mobility within the Union (e.g. US style "Green cards" for 3 rd country nationals). A third recommendation is to develop infrastructure to connect up the broader European economy.

2. The specific recommendations in this context are to increase government and EU spending in research [EU avg. 1.9\% $\rightarrow \sim 3 \%$ ] and post-graduate education [EU avg. 1.4\% $\rightarrow \sim 3 \%$ ], to allocate research grants according to the highest scientific standards, to create an independent European Agency for Science and Research, and to encourage private-sector R\&D via tax credits.

3. The recommendations here go in the direction of improving the incentives for countries to secure surpluses in good times, while increasing the room for manoeuvre for fiscal policies in bad times (Rainy day funds) within a framework of strengthened budgetary surveillance and more effective and flexible implementation of the SGP, while sticking to the 3\% ceiling. Also, budgetary responsibility would be enhanced by establishing independent Fiscal Auditing Boards in the Member States. At the same time, a higher degree of country differentiation based on the level public indebtedness should be introduced and the conditions under which the $3 \%$ deficit threshold can be breached should be modified. Another set of recommendations concerns coordination among national budgeting processes and dialogue between the president of a newlyestablished euro area Council, the relevant EU commissioner and the ECB president.

4. In this context, the Report recommends that EU convergence policy should concentrate on low-income countries rather than low-income regions, and that eligibility for access to EU assistance should be reviewed at the end of each programming period. Convergence funds allocated to low income countries should focus on two areas: (1) institution building, and (2) investment in human and physical capital, leaving beneficiaries free to decide how to allocate resources across different national projects. The Report also recommends EU restructuring support for workers who lose their job and need support to retrain, to relocate or to start a new business, as a complement to national welfare policies.

5. Here the Report makes a series of recommendations aimed at making the EU institutional framework clearer and more effective. Some funding, economic law enforcement and regulatory functions should be devolved from the Commission to independent European bodies, including decentralised implementation of 
market regulation, common growth and social cohesion agenda as well as management of the Single Market.

6. The idea is to reorganise radically that part of the budget for economic actions within the EU. There should be three funds: a growth fund (for the EU as a whole), a convergence fund (for low-income countries) and a restructuring fund (for individuals and firms affected by the restructuring process). This restructuring would enable the budget to play a more clearly defined role in achieving the Union's 2010 objectives. If the total budget amount remains unchanged, this will imply a major cut in agricultural spending and the devolution of spending for rural policy to the Member States. Financing the budget should move away from national contributions to sources with a clear EU dimension, including the devolution of some responsibility for budget execution to actors other than the Commission.

Commenting on the Sapir report, Nicoletti (2004) argues that the report covers a lot sometimes at the expense of focus, some priors are not questioned (e.g. cohesion, stability) and a hiatus exists between problems and policy tools to face them (most evident in the field of structural policies); finally, macroeconomic recommendations are sharper than structural ones. According to Pelkmans and Casey (2004) the main limit of the Sapir report is that it focuses only on the EU level of policy and governance while being silent about national strategies for growth. In particular, the member states' (in)capacities to reform and their lipservice rather than genuine commitment to deep and sustained investment in creating a (leading) knowledge economy are critical impediments to the Union achieving higher long-run economic growth. Second, the report deals extensively with market functioning, including labour markets, but refrains from sketching the microeconomic requirements for superior performance. Third, a more fundamental set of issues about market functioning in Europe remains virtually untouched in the Sapir report. They have to do with deeply engrained preferences and behavioural characteristics of Europeans today. Queries here include whether Europeans are and would like to remain riskaverters rather than risk-takers, whether Europeans are (still) entrepreneurial, whether Europeans still want higher economic growth given their current level of prosperity, and finally, whether today's inertia does not reflect an intergenerational conflict between the present and the future generations of Europeans. Wyplosz (2004), focusing on that part of the Sapir Report dealing with fiscal discipline, finds that there is a serious gap between the principles stated at the outset and the policy proposals. While the report expresses the intention of working through incentives it accepts without justification the imposition of rules. While it argues in favour of national ownership it seeks to reinforce the powers of the Commission. While it implicitly recognizes problems with the numerical targets $(3 \%, 60 \%)$ by proposing various ways of moving away from them, it still insists in placing them at the heart of their proposals. While it notes that long-term sustainability is at the heart of the SGP, they fail to recognize that this implies that the pact should be defined in terms of the long-run evolution of public debts, not annual budget deficits. Proposals on weakening SGP requirements for new accession countries and fiscal policy coordination are acceptable. Turning its attention to labour markets, Snower (2004) 
questions the Report's approach to leave their regulation (centralized wage bargaining and many other anticompetitive practices) to national governments. Based on the assumed symmetry between labour, goods and financial markets, Snower favours the EU Commission to be more broadly involved in the surveillance of national labour markets competitiveness and the adoption of innovative financial instruments capable of offsetting income and unemployment risks at the European level.

\section{On the Fiscal Discipline and Structural Reforms Nexus}

Two broadly opposite views have been expressed in the recent debate on the relations between fiscal policy and structural reform (Buti et al. 2007).

At one extreme, there is a "either/or view": structural reforms and deficit reduction are hardly compatible, so that policy authorities may be left with a dilemma. According to this view, excessively tight constraints to fiscal policy may be incompatible with the reform objectives of the Lisbon agenda, and the elements of flexibility for reforms introduced in the SGP with the 2005 reform are well-founded and need to be fully utilized. Several different arguments have been put forward in support of the "either/or view". Firstly, reforms may, at least temporarily, worsen budget balances due to direct budgetary costs (Razin and Sadka 2002). Secondly, a supportive fiscal stance may be needed in the short term to obviate to the temporary widening output gap associated with reforms. Indeed, while potential output is boosted by reforms, actual economic activity may only adapt gradually (Saint-Paul 2002; Hughes Hallett et al. 2004). This argument is strengthened by the claim that structural reforms, reducing tax progressivity and trimming welfare benefits, may lower the effectiveness of automatic stabilizers, thereby requiring discretionary fiscal policy to step in, in order avoid a sub-optimal degree of fiscal stabilization (Mabbett and Schelkle 2005). Finally, there are "political economy" considerations. Resistance to reforms coming from reform-losers can be overcome by means of compensation packages having a cost on the budget (Pierson 2001). Furthermore, given that governments may dispose of "political capital" in limited supply to enact unpopular measures, calling for further fiscal consolidation may use the political capital which could be better used for reforms (Eichengreen and Wyplosz 1998). Beetsma and Debrun (2004) show that if reforms are costly in the short run, the government is partisan and discount heavily the future, a deficit bias and a bias against reforms emerge. Fiscal constraints reduce the deficit bias but accentuate the reform bias. Hence, there may be a case for designing numerical deficit rules in such a way as to account for the budgetary impact of growth enhancing structural reforms.

At the opposite extreme, there is the "Brussels-Frankfurt consensus", as dubbed in Sapir et al. (2004): fiscal discipline and reforms not only are not incompatible, but tend to go hand in hand. A tight implementation of the EU fiscal rules could therefore be in line with the Lisbon objectives. Several arguments have also been advanced in support of the "Brussels-Frankfurt consensus". Firstly, there is the socalled "There-is-no-alternative (TINA) argument": there are instances in which there may simply be no alternative, and any well-conceived policy package needs to 
include both measures to redress budgetary imbalances and to re-launch growth (Rodrik 1996; Bean 1998; Calmfors 2001). Secondly, strong fiscal discipline may also act as a signalling device which reduces the resistance to reform (Deroose and Turrini 2005). Moreover, reforms of tax and benefit systems do not necessarily lead to lower the smoothing power of automatic stabilizers when the tax burden is very high (Buti et al. 2003a, b).

The analysis proposed by Buti et al. (2007) embeds both the above arguments. They develop a simple two-period model of a country in monetary union whose government decides about fiscal policy and structural reforms subject to a deficit constraint. Reforms are assumed to carry both a possible cost in term of temporary aggregate demand loss and a political cost. The point of departure of our analysis is that the relationship between budgetary policy and structural reforms needs to take into account the different time horizon over which the impact of the two policies produce effects on the level of economic activity. While higher deficits usually stimulate output in the short run at the expense of long-run potential output, reforms are very likely to boost potential output in the long term, but have more ambiguous effects on short-run economic activity. How the effects of fiscal policy and reforms are weighted against each other therefore crucially depend upon the time horizon of governments.

If reforms have an overall negative impact on economic activity in the short run, then the argument that tighter fiscal constraints may entail a less active reform stance holds. However, even admitting that reforms may reduce directly aggregate demand in the short term (e.g., due to increased job destruction and job reallocation, firm restructuring, etc.) the overall effect on output is ambiguous, since the stimulus to potential output also induces a more accommodating monetary policy stance and improves export competitiveness. When the positive indirect effects on short-term output dominate, a possible complementarity between fiscal discipline and reforms emerges since under these conditions reforms are alternative policy tools to boost short-run output. The emergence of a complementarity relationship is more likely the more short-sighted the government: the complementarity relationship is indeed a short-run phenomenon, while in the long run both fiscal discipline and reforms are likely both to increase potential output, being therefore substitute.

Hence, whilst looser fiscal constraints may boost reforms when governments have a long time horizon, they are more likely to lead to the opposite effect when governments are myopic and focus on boosting output in the short term. They provide in the paper some empirical evidence supporting these findings. In a panel of EU countries over the period 1971-1998, they find that the introduction of the EU fiscal framework seems to have discouraged labour market reforms in governments far from elections (therefore likely to be relatively forward-looking) and to have encouraged instead reforms in the labour market for governments facing elections in the current or subsequent year (therefore likely to be relatively myopic).

\section{Conclusions and Further Discussions}

The SGP was reformed in such a way to cater for a possible trade-off between reforms and budgetary discipline. However, in order to prevent moral hazard and a 
dilution of the Maastricht deficit threshold, the conditions under which more flexibility would be granted in exchange of reforms are tight. Buti et al. (2007) show that such restrictive conditions are well grounded if government short-sightedness prevails: in this case, a "soft" application of the Pact may actually discourage rather than trigger reforms. Analogously, their analysis shows that the revamped Lisbon focused on growth and jobs, by raising the output target of governments would raise reforms efforts by governments, with an impact on deficits that would instead again crucially depend on governments' time horizon (more fiscal discipline in case of myopic governments). Additionally, they document that in the case of myopic governments there could a more ambitious reform effort to reach the Lisbon objectives when fiscal constraints are tighter.

The implications of governments' short-sightedness on the fiscal discipline and structural reform nexus discussed in Buti et al. (2007) builds on the acceptance of the current institutional framework. By contrast, other studies focus on the inner weaknesses of the LS and those of the current fiscal discipline rules in Europe. It has been overlooked that structural changes cannot be implemented quickly but need many years for accomplishment and are really costly. The expectations to have very quick results brought disappointment. The parallel objective of raising employment was based on a correct consideration that the European work force is underemployed, predominantly because it is spending too little of their lives at work and is working too few hours (Blanchard 2004). The symbolic goal of outperforming the US and other parts of the world showed to be least justified and brought more confusion then benefits to the stakeholders of the Strategy, the European citizens and their neighbours. Opposing Europe to other parts of the world instead of promoting fruitful cooperation was the mistaken idea, which has additionally neglected the fact that the openness of the European economy could be an additional source of economic growth.

Another key issue has been the lack of determined political action (High Level Group 2004). As discussed in Sect. 3, the OMC used in the Lisbon Strategy has no formal enforcement means at its disposal. Therefore, only tasks voluntarily chosen and accepted by the member countries can be achieved under the OMC. The only pressures on countries can be exerted through mutual information and assessment. This method of coordination proved so far to be efficient only in cases when a particular action was not in an area of conflicts among participants. But it was rather inefficient in cases when the interests of member countries differed seriously. Countries are not willing to take part in the "blaming and shaming" process because of fear of being criticized by other countries in the case of differing interests. Finally, when countries do not clearly see a common interest in implementing a given change, the national governments will not be really committed to convince their parliaments and citizens to such changes and the action will remain on paper.

The European Commission, as a "natural" institution to address these issues, cannot do so unless its authority is clearly established. In turn, this calls for two additional points in the EU debate on institutional reforms: the definition of the role to be assigned the budget and the rules relating to fiscal policy (Majocchi 2003). The greatest concern of the drafters of the Treaty of Maastricht was to prevent member states from having divergent economic policies that could jeopardise the Union's monetary stability. Even in specific sectors of Community competence, whenever 
fiscal measures are involved, unanimity is required (Tosato 2003). Furthermore, new resources must also pass through extenuating national ratification procedures. Another constraint on the use of the budget as an instrument of economic policy is its small size, which prevents it from being used effectively as an instrument of economic policy. Furthermore, expenditures are aimed at ensuring the financing of common policies; with a considerable part of the budget absorbed by the Common Agricultural Policy and redistribution going in favour of the more disadvantaged areas only marginal resources are left for new policies: the environment, R\&D, industry, trans-European networks.

The model of fiscal policy coordination adopted in the SGP tends to leave the responsibility for stabilisation policies prevalently up to the single member states and merely asserts the need for coordination of fiscal policies at the European level. But the drawback is that coordination is carried out in the Council, which can only adopt recommendations and has no coercive means with which to oblige the member states to abide by them. The problem then is whether the stabilisation objectives should be pursued through changes in the community budget or through coordination of the fiscal policies managed by the member states. In both cases, an essential condition for implementing reforms of the fiscal policies rules in Europe rests on strengthening the responsibility of the budget authority made up of the European Parliament and the Council of Ministers, by granting it the power to decide on community public spending (Majocchi 2003).

\section{References}

Allsopp C (2002) The future of macroeconomic policy in the European Union. Bank of England external MPC unit discussion paper 7

Bean C (1998) Monetary policy under EMU. Oxford Rev Econ Policy 14:41-53

Beetsma R, Debrun X (2004) Reconciling stability and growth: smart pacts and structural reforms. CEPR discussion paper 3930

Begg D, Canova F, De Grauwe P, Fatás A, Lane P (2002) Surviving the slowdown: monitoring the European Central Bank 4 CEPR

Bini-Smaghi L, Casini C (2000) Monetary and fiscal policy co-operation: institutions and procedures in EMU. J Common Mark Stud 38:375-391

Blanchard O (2004) The economic future of Europe. NBER working paper 10310

Blanchard O, Giavazzi F (2003) Improving the SGP through a proper accounting of public investment. CEPR discussion paper 4220

Blaszczyk B (2005) The Lisbon strategy: a tool for economic and social reforms in the enlarged European Union. Centre for social and economic research working paper 310

Buiter W, Grafe C (2004) Patching up the pact: some suggestions for enhancing fiscal sustainability and macroeconomic stability in an enlarged European Union. Econ Transit 12:67-102

Buti M, Eijffinger C, Franco D (2003a) Revisiting the stability and growth pact: grand design or internal adjustment? CEPR discussion paper 3692

Buti M, Martinez-Mongay C, Sekkat K, Van den Noord P (2003b) Automatic fiscal stabilisers in EMU: a conflict between efficiency and stabilisation? CESifo Econ Stud 49:123-140

Buti M, Röger W, Turrini A (2007) Is Lisbon far from Maastricht? Trade-offs and complementarities between fiscal discipline and structural reforms. European Commission mimeo

Casella A (2001) Tradable deficit permits. In: Brunila A, Buti M, Franco D (eds) The stability and growth pact. Palgrave, New York

Centre for European Reform (2004) The Lisbon scorecard IV. The status of economic reform in the enlarging EU. CER, London 
Centre for European Reform (2005) The Lisbon scorecard V. Can Europe compete? CER, London

Calmfors L (2001) Unemployment labour market reform and monetary union. J Labor Econ 19:265-289

Deroose S, Turrini A (2005) The short-term budgetary impact of structural reforms: evidence from a panel of EU Countries. CEPR discussion paper 5217

Eichengreen B, Wyplosz C (1998) The stability and growth pact: more than a minor nuisance? Econ Policy 13:65-104

European Commission (2000) Presidency conclusions. Lisbon European Council 23 and 24 March 2000, Brussels. http://www.consilium.europa.eu/ueDoes/ems_Data/does/pressData/en/ec/00100-rl.en0.htm

Fatás A, von Hagen J, Hughes Hallet A, Strauch R R, Sibert A (2003) Stability and growth in Europe: towards a better pact. Monitoring European Integration 13 CEPR London

High Level Group (2004) Facing the Challenge The Lisbon strategy for growth and employment. Report from the high level group chaired by Wim Kok

HM Treaury (2004) The stability and growth pact: a discussion paper.

Hughes Hallett A, Hougaard Jensen SE, Richter C (2004) The European economy at the cross roads: structural reforms fiscal constraints and the Lisbon agenda. CEBR Copenhagen Business School mimeo

Mabbett D, Schelkle W (2005) Bringing macroeconomics back in to the political economy of reform: the Lisbon agenda and the 'fiscal philosophy' of EMU. Birbeck College mimeo

Majocchi A (2003) Fiscal policy rules and the European constitution. Int Spect 2:27-42

Nicoletti G (2004) An agenda for a growing Europe: a comment. Available at http://wwwfrdborg/ images/customer/copy_0_la_presentazione_di_giuseppe_nicoletti_1partepdf

Pelkmans J, Casey J P (2004) Can Europe deliver growth? The Sapir Report and beyond CEPS policy brief

Pierson P (2001) The new politics of the welfare state. Oxford University Press, Oxford

Pisani-Ferry J (2002) Fiscal discipline and policy coordination in the Eurozone: assessment and proposals. In: Budgetary policy in $\mathrm{E}(\mathrm{M}) \mathrm{U}$ : design and challenges. Proceedings of a seminar at the Dutch Ministry of Finance

Razin A, Sadka E (2002) The stability and growth pact as an impediment to privatizing social security. CEPR discussion paper 3621

Rodrik D (1996) Understanding economic policy reforms. J Econ Lit 34:9-41

Saint Paul G (2002) Employment protection innovation and international specialization. Eur Econ Rev 46:375-395

Sapir A (2003) An agenda for a growing Europe. Report of an Independent high-level study group established on the initiative of the President of the European Commission

Sapir A, Aghion P, Bertola G, Hellwig M, Pisani-Ferry J, Rosati D, Viñals J, Wallace H, Buti M, Nava M, Smith PM (2004) An agenda for a growing Europe. The Sapir report. Oxford University Press, Oxford

Snower D (2004) Comments on Andre Sapir structural reforms and economic growth in the EU: is Lisbon the right agenda?

Tosato GL (2003) The vertical distribution of competences in the EU draft constitutional text. Int Spect 2:43-58

Von Hagen J (2003) Fiscal sustainability in EMU from the stability and growth pact to a sustainability council for EMU. unpublished manuscript

Wyplosz C (2002) Fiscal policy: institutions versus rules. CEPR discussion paper 3238

Wyplosz C (2004) Proposals for fiscal discipline in the Euro zone. available at http://wwweuro50org/ 2004/brussels04/Wyploszdoc 